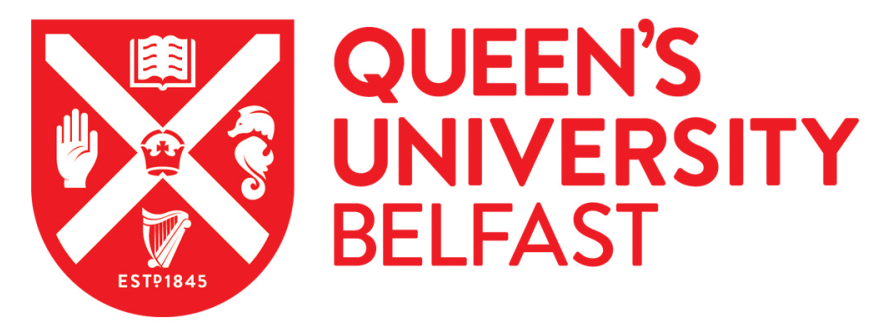

\title{
Re-assessing the vertical distribution of testate amoeba communities in surface peats: implications for palaeohydrological studies
}

Roe, H. M., Elliott, S. M., \& Patterson, R. T. (2017). Re-assessing the vertical distribution of testate amoeba communities in surface peats: implications for palaeohydrological studies. European Journal of Protistology, 60, 13-27. https://doi.org/10.1016/j.ejop.2017.03.006

Published in:

European Journal of Protistology

Document Version:

Peer reviewed version

Queen's University Belfast - Research Portal:

Link to publication record in Queen's University Belfast Research Portal

\section{Publisher rights}

Copyright 2017 Elsevier.

This manuscript is distributed under a Creative Commons Attribution-NonCommercial-NoDerivs License

(https://creativecommons.org/licenses/by-nc-nd/4.0/), which permits distribution and reproduction for non-commercial purposes, provided the author and source are cited.

\section{General rights}

Copyright for the publications made accessible via the Queen's University Belfast Research Portal is retained by the author(s) and / or other copyright owners and it is a condition of accessing these publications that users recognise and abide by the legal requirements associated with these rights.

Take down policy

The Research Portal is Queen's institutional repository that provides access to Queen's research output. Every effort has been made to ensure that content in the Research Portal does not infringe any person's rights, or applicable UK laws. If you discover content in the Research Portal that you believe breaches copyright or violates any law, please contact openaccess@qub.ac.uk. 


\title{
Re-assessing the vertical distribution of testate amoeba communities in surface peats: implications for palaeohydrological studies
}

Helen M. Roe ${ }^{1}$, Suzanne M. Elliott. ${ }^{1}$ and R. Timothy Patterson ${ }^{2}$

\author{
${ }^{1}$ School of Natural and Built Environment, Queen's University Belfast, \\ Belfast, BT7 1NN, United Kingdom \\ ${ }^{2}$ Ottawa-Carleton Geoscience Centre and Department of Earth Sciences, \\ Carleton University, Ottawa, Ontario, K1S 5B6, Canada
}

Corresponding author: h.roe@qub.ac.uk 


\begin{abstract}
Testate amoeba-derived transfer functions are frequently used in peatland palaeohydrological studies and involve the development of training sets from surficial peats. However, within acrotelmic peats, considerable vertical variation in assemblage composition can occur, particularly along Sphagnum stems, which may limit the representation of the associated 'contemporary' testate amoeba samples as analogues for the peatland surface. This paper presents contiguous testate amoeba assemblage data from nine monoliths collected from different peatland microforms (hummock, hollow, lawn) in three Sphagnum dominated ombrotrophic peatlands in Ontario and Quebec, eastern Canada. The aim is to: i) gain a greater understanding of the vertical distribution of xerophilous/hygrophilous taxa along Sphagnum stems; ii) determine the vertical extent of live/encysted taxa along this gradient; and iii) assess the significance of this distribution on surface sampling protocols. The results show that testate amoeba communities in the uppermost acrotelmic peat layers display considerable variability. This may reflect a complex interplay of abiotic and biotic controls, including moisture, temperature, light and other characteristics, food availability, and mineral particle availability for test construction. These findings underline the complexity of testate amoeba community structure and highlight the importance of analysing both living and dead Sphagnum stem sections when developing calibration sets.
\end{abstract}

Key words: testate amoebae, encystment, live taxa, vertical zonation, Sphagnum peatlands, microforms 


\section{Introduction}

Testate amoebae have been widely used as proxies for hydrological change and for inferring palaeoenvironmental conditions in peatlands (e.g. Hendon et al. 2001; Swindles et al. 2009; Loisel and Garneau 2010; Payne et al. 2011; Lamentowicz et al. 2015). Surface wetness reconstructions are commonly inferred from transfer functions, which aim to model the relationship between contemporary testate amoeba assemblages and depth to water table (Woodland et al. 1998; Hendon and Charman 2004; Charman et al. 2007). These are in turn applied to down core assemblages in contemporary peatland sites. However, it has long been known that considerable variability exists within testate amoeba communities in surficial peat layers (Heal 1962; Buttler et al. 1996; Mitchell et al. 2008). The ecology of testate amoebae inhabiting Sphagnum stems and in surficial peats has been shown to be controlled by a number of physical parameters, for example, moisture, light, food resources, temperature and the availability of mineral material for test construction (Heal 1962; Meisterfeld 1977; Charman et al. 2000; Booth 2002; Mieczan 2010).

Below the surface, the acrotelm represents the aerobic uppermost layer of peatlands and varies in depth from between $5-50 \mathrm{~cm}$, whereas the underlying catotelm has a lower rate of residual peat decay (Clymo 1984; Belyea and Clymo 2001). The vertical depth of the acrotelm is dependent upon surface microtopography (e.g. hummock, hollow and lawn microforms), the interaction between water tables and processes of peat accumulation (Belyea and Clymo 2001; Quinty and Rochefort 2003; Rydin and Jeglum 2006). However, the concept of two distinctive layers is arguably too simplistic, as the acrotelm contains anaerobic sections and aerobic channels that can extend into the catotelm via vascular plant roots (Hayward and Clymo 1983; Morris et al. 2011). Notwithstanding this, the boundary between the acrotelm and catotelm has been considered to occur at the minimum water table in summer (Clymo 1984). Other criteria that have been used to distinguish the boundary include changes in humification (Charman et al. 1999) and bulk density of the peat (Yu et al. 2003). The acrotelmic layer also shows considerable internal variation. The organic material here may be fibrous or pseudofibrous (with plant remains such as stems, rhizomes and root matter recognizable), or may be lost but the peat may still retain integral structure. As mosses and other plant communities die, fibrous 
material is added to the peat, providing physical structure for the new upwards growth of mosses (Malmer et al. 1994). Decomposing litter content also varies within the oxic, acrotelmic peat layers, and changes with depth, eventually becoming covered in the catotelm by rising water tables (Rydin et al. 2006).

In order to quantify hydrological changes within peatlands through transfer function models, modern analogues of testate amoeba assemblages must be sampled from these surficial peats. A number of methodological approaches have been employed to achieve this. In many European studies, for example, the uppermost $1 \mathrm{~cm}$ of surficial peat has been used to process testate amoeba samples after the removal of the Sphagnum capitulum (e.g. Woodland et al. 1998; Swindles et al. 2009). This narrow vertical interval has been selected to ensure that a sample representing only the very recent period is obtained. A slightly modified approach was applied by Swindles et al. (2015) in which the entirety of the green (living) moss fraction and $1 \mathrm{~cm}$ of the underlying brown Sphagnum were sampled. In other studies, assemblages have been characterized by identifying an 'upper' surficial peat section, which comprised living, vertical Sphagnum stems, and a 'lower' section, comprising brown, humified Sphagnum with collapsed stems (e.g. Schönborn 1963; Booth 2002). Such studies have aimed to explore vertical variations in assemblage composition in regions where there is considerable thickness of living Sphagnum present. The study of Booth (2002), for example, which was undertaken in Michigan, USA, involved sampling the entire green Sphagnum layer and a $\sim 10 \mathrm{~cm}^{3}$ lower sample from immediately below the green stems. In this case only the lower samples were included in the training set used for calibration model development (Booth 2002).

In spite of the large number of studies that have examined surficial peat samples, the vertical distribution of living testate amoeba communities in surficial Sphagnum stems remains largely unexplored, but is critical for understanding species-environment relationships. Environmental gradients (e.g. moisture) have been shown to control the vertical variation of 'live' and 'dead' assemblages, which can be distinguished through the staining of living protoplasm with Rose Bengal (Schönborn 1963; Meisterfeld 1977, 1978; Scott and Medioli 1980). Light appears to be a particularly important factor influencing the distribution of species containing symbiotic zoochlorellae, such as 
Archerella flavum (Schönborn 1963; Gilbert and Mitchell 2006; Mazei and Bubnova 2007). Similar symbiotic species include Hyalosphenia papilio and Heleopera sphagni, which live in the chlorophyllous upper few centimetres of peatlands (i.e. living green stems) to enable photosynthesis of algae to occur. Taxa that use xenosomes to build tests such as Difflugia spp., Trigonopyxis arcula and Centropyxis spp. have been observed in lower stem positions (Payne and Pates 2009) than idiosomic taxa such as Euglypha spp. (Heal 1962; Schönborn 1962).

Testate amoebae also have the ability to encyst for long periods of time (Ogden and Hedley 1980; Foissner 1987). However, there is a limited understanding of the vertical distribution of encysted testate amoebae and the potential factors controlling this state, as encysted species have typically not been distinguished from live or dead individuals in most modern (i.e. surficial peat) and palaeoecological studies (Vincke et al. 2004; Jassey et al. 2011). Encystment is nevertheless considered to be a response to unfavourable environmental conditions such as desiccation (Lousier 1974; Woodland et al. 1998; Booth and Zymunt 2005), frost (Mitchell et al. 2000; Warner et al. 2007) or decreases in food availability (Laminger 1984). One challenge in understanding how testate amoeba communities respond to such unfavourable conditions relates to a lack of seasonal monitoring of species-environment relationships. A notable exception was a study by Sullivan and Booth (2011) who employed data loggers to measure relative humidity within the upper few centimetres of Sphagnum stems in 11 peatlands in Pennsylvania and Wisconsin, USA. The results were used to determine the influence of short-term environmental variability on testate amoeba communities. This study highlighted the role of surface vegetation, as well as changes in precipitation and evapotranspiration in controlling sub-annual testate amoeba community composition variability.

Many other studies have examined testate amoeba assemblages from short $(<50 \mathrm{~cm})$ cores collected from acotelmic peats to reconstruct recent hydrological change. Testate amoeba-inferred water table fluctuations from dated cores of acrotelmic peats, for example, have been compared to instrumental records of climate change to validate calibration models (Charman et al. 2004, 2009; Charman 2007). There is, however, a poor understanding of the relationship between live/dead and encysted testate amoebae in deeper acrotelmic peats and the significance that this might have for 
interpreting model-inferred hydrological changes. There is also a need to examine the vertical variation in testate amoeba assemblages in regions with deep acrotelms, for example, in dry, continental areas where the living parts of mosses can span a large vertical range. In this paper we examine the live/dead assemblage composition of different microforms (hummock, hollow, lawn) from three ombrotrophic peatlands in continental eastern Canada to make new inferences about the ecology and distribution of testate amoeba taxa in surficial peat environments. The three study sites in Ontario and Quebec are all characterised by high mean summer temperatures (July averages range from 26.1$26.5^{\circ} \mathrm{C}$ ) (Supplementary Table 1A), and deep acrotelmic peats. Floristically, they are dominated by a similar range of Sphagnum species and vascular plants. As well as providing a new assessment of the ecology of testate amoebae communities in surficial peatlands, the study provides new insights into the selection of sampling ranges in these environments for quantitative palaeohydrological reconstructions.

\section{Site description}

The three study peatlands, Mer Bleue Bog, Mirabel Bog and Alfred Bog, are all ombrotrophic peatlands in the central St Lawrence Lowlands region of eastern Canada (Fig. 1). This region is characterized by thick acrotelmic peat deposits that typically extend up to $50 \mathrm{~cm}$ below the surface, which is ideal for sampling along a vertical hydrological gradient within hummock, hollow and lawn topographies. Mer Bleue Bog $\left(45^{\circ} 24^{\prime} \mathrm{N} ; 75^{\circ} 31^{\prime} \mathrm{W}\right)$, located ca. $15 \mathrm{~km}$ east of Ottawa, covers $28 \mathrm{~km}^{2}$ and is characterized by three drainage 'arms' separated by alluvial sand ridges (Mott and Camfield 1969; Elliott et al. 2011). The northern arm is domed (Joyal, 1970), with peat depths of 5-6 m, decreasing to 1-2 m around the margins. Surface vegetation is dominated by Sphagnum species (e.g. S. capillifolium, S. fuscum, S. magellanicum and S. angustifolium) and ericaceous shrubs such as Ledum groenlandicum, Chamaedaphne calyculata and Kalmia angustifolia.

Mirabel Bog $\left(45^{\circ} 41^{\prime} \mathrm{N} ; 7^{\circ} 02^{\prime} \mathrm{W}\right)$, formerly known as Saint-Canut Bog (MacPherson, 1967; Muller et al. 2003), is a $2.15 \mathrm{~km}^{2}$ ombrotrophic peatland situated ca. $45 \mathrm{~km}$ northwest of Montreal (Fig. 1). The central part of the bog comprises a well-defined hummock and hollow topography dominated by S. capillifolium and S. magellanicum. Other vegetation includes C. calyculata, 
Polytrichum strictum, Eriophorum spissum, K. angustifolia, Kalmia polifolia and Viburnum cassinoides. The peatland also supports stunted forms of Picea mariana, Betula populifolia and Larix laricina. Alfred Bog $\left(45^{\circ} 29^{\prime} \mathrm{N} ; 74^{\circ} 48^{\prime} \mathrm{W}\right)$ is situated $75 \mathrm{~km}$ east of Ottawa. It is a $42 \mathrm{~km}^{2}$ peatland, the largest in the Southern Ontario Canadian Shield. Dominant moss species include S. capillifolium, S. fuscum, S. magellanicum, Polytrichum commune and Pohlia nutans. Ericaceous shrubs dominate the open peatland and include C. calyculata, K. polifolia, K. angustifolia, L. groenlandicum and Vaccinium oxycoccus.

\section{Material and Methods}

To investigate the vertical distribution of testate amoebae in the uppermost sections of peat, nine monoliths $(10 \times 10 \times 20 \mathrm{~cm})$ were collected from the three study sites, Mer Bleue, Mirabel and Alfred Bogs representing a range of hummock, hollow and lawn microsites (Fig. 2). The rationale behind sampling over a wide hydrological gradient was to gain insights into species-environment relationships and is similar to previous investigations that have examined the surficial distribution of testate amoebae in mires (Lamentowicz et al. 2008; Jassey et al. 2011; Lamarre et al. 2013). The sampling extent of the monoliths varied (between ca. 15-20 cm) and was dependant on the depth of the living (green) Sphagnum stems at each sampling point. Each sampling site covered a range of vegetation species and water table depths. Vegetation was identified in the field and the laboratory using the keys of Crum and Anderson (1981), Daniels and Eddy (1990) and Bastien and Garneau (1997). To measure water table depths, 'single-shot' readings were taken from the monolith sampling stations using wooden rods. Holes were excavated using a soil auger and sharp knife. The rods were left in the holes for 20 minutes to allow the readings to equilibriate. The use of single-shot water table measurements for testate amoeba-based hydrodrological studies has been debated previously (e.g. Bobrov et al. 1999; Booth 2008; Swindles et al. 2015). Whilst the method only provides a 'snapshot' of the seasonal water table variability, it has been shown to adequately represent the relative hydrological status of sample locations and is sufficient to drive a hydrological gradient for transfer function development (Swindles et al. 2015). Sampling should not be carried out, however, during 
periods of extreme weather such as summer drought or after heavy rain (Charman et al. 2007; Swindles et al. 2009). To this end, the monoliths were all collected on dry days during the month of May at the same time of day (before noon). Sampling was undertaken after a period of approximately two weeks when no rain had fallen in the region. After collection, the monoliths were carefully sealed in polythene bags prior to transportation.

In the laboratory, each monolith was split in half vertically to expose the structure and vegetation composition (cf. Buttler et al. 1996). Preliminary results showed that there was a transition between the live and more decomposed stems, which further justified the need to sample at high resolution. Each half was then cut at contiguous $1 \mathrm{~cm}$ intervals to analyse the vertical variation of testate amoebae (cf. Meisterfeld 1978; Niinemets et al. 2011). Sub-samples from one half were used to determine moisture content, bulk density and colorimetric peat humification, while those from the other half were stained using Rose Bengal and used for testate amoeba analysis. Samples were oven dried at $105^{\circ} \mathrm{C}$ for 24 hours and re-weighed to determine moisture content (Chambers et al. 2011). A known volume of peat was also measured at $1 \mathrm{~cm}$ intervals and oven dried at $105^{\circ} \mathrm{C}$ for 24 hours, then weighed to determine bulk density (Tolonen et al. 1992). Rose Bengal stain was added ca. four hours after monolith collection to stain the living protoplasm (Scott and Medioli, 1980; Bernhard, 2000). Samples were prepared following a modified version of the method by Hendon and Charman (1997) and Charman et al. (2000). Instead of boiling, the samples were heated gently for 10 minutes as the ethanol would denature the living tests (cf. Booth et al. 2010). Testate amoebae were identified largely with reference to the key of Charman et al. (2000), although a number of other keys, plates and descriptions were consulted, including Penard (1902), Loeblich and Tappan (1961), Corbet (1973), Ogden and Hedley (1980) and Booth (2002). Subtle differences in morphology were noted during routine counting, for example, the number of pores in specimens of Hyalosphenia papilio (Booth and Meyers, 2010). Since the study was undertaken, phylogenetic work has led to some re-classifications (for example, several taxa within the Nebela tincta-bohemica-collaris group have been re-classified; Kosakyan et al. 2013). In this 
paper, however, we adhere to the terms Nebela tincta and Nebela collaris sensu stricto (cf. Charman et al., 2000).

The number and type of taxa that were encysted from the monoliths was also recorded. Encystment was identified on the basis of a closed aperture and/or with a mass of protoplasm (cf. Heal 1962; Corbett 1973). More specifically, encysted forms were recognized for having an operculum consisting of a plug of organic material surrounding the inner aperture of the test wall and a thickened anterior cyst wall. This has been recognized in forms of Cryptodifflugia oviformis and Cryptodifflugia leachi (Nicholls 2006). As in previous studies, encysted taxa were summed with the total live count because individuals normally represent $<2 \%$ of the sample (Vincke et al. 2004; Beyens et al. 2009).

In addition to plotting the live and dead testate amoeba assemblages with depth for each of the nine monolith profiles, Detrended Correspondence Analysis (DCA) was carried out to explore the inter- and intra-microform characteristics of the testate amoeba communities and to examine associations between species. As the main emphasis in undertaking this analysis was to better understand the distribution of living testate amoeba species, only samples that yielded $>5 \%$ live specimens for at least one taxon were included in the analysis.

\section{Results and Discussion}

In general, the zone where live testate amoebae were present varied according to microform (hummock, hollow, lawn) in the three study sites and with dominant Sphagnum type (e.g. S. fuscum, S. capillifolium, S. magellanicum and S. angustifolium). The relationship between live and encysted taxa in each of the nine monoliths is shown in Figures 3-5. The DCA plot (Fig. 6), shows that the testate amoeba assemblages were well clustered for the hummock samples but there was some overlap between the hollow and lawn samples. Axis one in the plot appears to be strongly influenced by depth to water table, with the species that are common indicators of dry conditions (e.g. Assulina seminulum, Trigonopyxis arcula) plotting on the left of the figure and established wet indicator species (e.g. Archerella flavum, Hyalosphenia elegans) in the centre and right (Fig. 6). The overlap and apparent reverse ordering of the lawn and hollow samples may reflect the similarity in water table 
measurements between these microforms (Supplementary Table 1B). It may also suggest that other ecological gradients e.g. light and temperature had an influence on assemblage composition. A summary of the vertical distribution of the total live taxa in the hummock, hollow and lawn microsites is given in Figure 7, whilst Figure 8 provides a simplified summary of the relationship between live testate amoeba species, water table depths and microform vegetation. Emphasis is placed in the following sections on examining the assemblages from the upper and middle sections of the monolith profiles for each microform, i.e. from the green (=living) or 'transitional' zone samples that yielded living testate amoebae (Figs. 3, 4, 5). The deeper, semi-humified to humified parts of the profiles that primarily yielded dead specimens may represent different environmental conditions to those that prevailed at the time of sampling, potentially spanning several decades. As we have no chronological control for the profiles (such as that afforded by ${ }^{210} \mathrm{~Pb}$ dating; Appleby 2001), and no means of determining the rates at which the surficial, green Sphagnum layer decomposes and becomes incorporated to the humified peat, only brief reference is made to the lower assemblages.

\section{Hummock microforms}

Counts above 150 specimens were difficult to achieve in the hummock profiles, particularly when water table depths exceeded $50 \mathrm{~cm}$ below the peat surface (Fig. 3B and 3C). Xerophilous communities dominated by Assulina muscorum and A. seminulum were typical of the S. fuscum and S. capillifolium hummock microforms (Fig. 3). Other taxa that favour dry conditions included Hyalosphenia subflava, Trigonopyxis arcula and Cyclopyxis arcelloides. Xenosomic species increased in abundance with depth and photophilic species were found in the upper aerobic Sphagnum that contain symbiotic algae (zoochlorellae). For example, Phryganella acropodia was only present in the lower depths of the Sphagnum profile (Fig. 3C). This could be due to the increased availability of material for test construction (e.g. minerals and diatoms) (cf. Booth 2002; Mitchell and Gilbert 2004). As depth increased, the apertures of $P$. acropodia became increasingly armoured with mineral particles, making it difficult to distinguish them from small forms of Cyclopyxis arcelloides.

Interestingly, in the hummock profiles (Fig 3), there is evidence for a zonation in the assemblages between the upper $5 \mathrm{~cm}$ of the green Sphagnum stems, and the underlying 'transitional' 
layer where the stems typically were decomposing and where colour changes (notably an increased dominance of red-brown stems) were observed (Figs. 2, 3). For example, in the hummock profile in Fig. 3A, A. muscorum reached peak abundances of $60-80 \%$ in the uppermost $3-4 \mathrm{~cm}$ (green layer), in contrast to $H$. elegans which attained peak frequencies (10-30\%) between 5-9 cm (transitional layer). In a study of the vertical micro-zonation of testate amoebae from re-colonizing Sphagnum peatlands in the Swiss Jura Mountains, Mitchell and Gilbert (2004) suggest that competitive exclusion may occur between species that are closely related. They note that A. flavum, A. muscorum and $H$. papilio reach higher abundances in the capitulum compared with Amphitrema wrightianum, A. seminulum and $H$. elegans. Patterns of species micro-distribution may also be explained by specific environmental constraints. For example, the observed changes could be a response to the increased sensitivity of taxa to desiccation (e.g. A. muscorum). A decrease in moisture at the capitulum can lower $\mathrm{pH}$ and ion concentrations relative to the Sphagnum stem (cf. Mitchell et al. 2000). Some taxa are known to have a preference for low $\mathrm{pH}$ and moisture environments, including A. muscorum and A. flavum (cf. Lamentowicz and Mitchell 2005; Swindles and Roe 2007), whilst A. seminulum can reproduce more successfully at greater depths where there is a thicker water film along the Sphagnum branches (Mitchell et al 2008). It is interesting to note that the sub-division noted above between the assemblages from the upper stems (above $4 \mathrm{~cm}$ ) and from a few centimetres below is not particularly apparent in the DCA plot; the samples from different hummock depths are well mixed. This suggests that in comparison to the variation in the dataset as a whole, the assemblages are not that different.

The vertical distribution of living testate amoebae $(>2 \%)$ in the hummock microforms spanned a maximum of $12 \mathrm{~cm}$, and comprised up to $55 \%$ of the total assemblage. Assulina muscorum dominated the live specimens up to a depth of $10 \mathrm{~cm}$ (Fig. 3). Other live taxa included A. seminulum, H. elegans, Heleopera sylvatica, H. subflava, Nebela militaris and Trinema lineare (Fig. 3A and 3B; Fig 8). In a study in the Middle Volga region (Russia), Mazei and Tsyganov (2007) recorded maximum live abundances of testate amoebae in dry habitats, such as hummocks of between $22-27 \%$. Robroek et al. (2007) and Sullivan and Booth (2011) suggest that despite the increasing distance of the hummock surface from the water table, hummocks can contain a greater seasonal storage of moisture 
due to their compact structure. The common hummock-forming species Sphagnum fuscum, for example, has the ability to retain water more effectively than some lawn and hollow-forming Sphagnum species (e.g. S. rubellum, S. magellanicum) because of its high capitula density and efficient capillary system (Robroeck et al. 2007; McCarter and Price 2012). As a result, this would reduce the impacts of short-term environmental variability (e.g. desiccation) on these microforms in comparison to hollows or lawns, and may explain why a high abundance of live taxa were found in the uppermost $5-10 \mathrm{~cm}$ of the hummocks.

\section{Lawn microforms}

Counts between $70-100$ specimens were achieved in the upper $0-3 \mathrm{~cm}$ of the lawn profiles, rising to $>150$ below this (Fig. 4). There was a co-dominance of xerophilous taxa such as A. muscorum and $H$. subflava, as well as hygrophilous taxa such as Heleopera petricola and H. elegans. Within the deeper, unhumified (green) parts of the lawn profiles the testate amoeba communities become increasingly uniform in composition (Fig. 4). This could be due to a decrease in light and/or temperature (Mitchell and Gilbert 2004; Jassey et al. 2011). Heleopera sphagni and H. papilio, for example, both attain highest abundances in the uppermost $5 \mathrm{~cm}$ of the $S$. capillifolium lawn microforms then decline rapidly below this (Fig. 4A and 4B). Both taxa have symbiotic zoochlorellae and require light, therefore their maximum abundance would be at the top of the Sphagnum stem (cf. Booth 2002). Cyclopyxis arcelloides, however, appears more frequently below $8 \mathrm{~cm}$ in the transitional layer where the stems are starting to decompose (Fig. 2). This may reflect the enhanced availability of mineral particles for test construction or increased availabililty of food sources.

In the more humified samples below the transitional layer the assemblages show further changes, most notably increases in Nebela minor and Nebela penardiana (Fig. 4). A centimetre of peat in these deeper parts of the profiles is likely to represent a longer time interval than the same thickness of sample in the green, stem-dominated horizons because of the influence of decompositional processes and the compression of the stems that occurs with decay. Without chronological control it is not possible to ascertain, however, what time interval the lower assemblages represent, or what 
relationship, if any, they show with the environmental conditions that prevailed at the time of sampling.

Co-dominance of live wet and dry indicator taxa was most notable in the lawn profiles. This may reflect the fact that the living Sphagnum stems in the lawn habitats are characterised by intermediate moisture characteristics for most of the year and are thus able to satisfy the niche requirements of species with tolerance ranges spanning both ends of the moisture spectrum. As watertable measurements were only taken at the time of sampling it is not possible to assess this further. Sullivan and Booth (2011) note that it is the increase in short term variability that results in the appearance of taxa at opposing ends of the moisture gradient in fossil assemblages from these environments. The presence of mixed wet and dry assemblage constituents in the lawn samples may explain why these samples showed a weaker degree of clustering in the DCA plot than the hummock and hollow samples (Fig. 6). This pattern may also suggest that factors other than hydrology are influencing the assemblages.

The vertical extent of living testate amoebae $(>2 \%)$ in the lawn microforms spanned a maximum of $19 \mathrm{~cm}$, and comprised up to $50 \%$ of the total assemblage (Fig. 4A). This is the largest depth range encountered during the study (Fig. 7). The majority of the live taxa consisted of $H$. petricola and $H$. sphagni, which occurred within the upper $5 \mathrm{~cm}$. As noted above, the dominance of these species in the green, chlorophyllous Sphagnum stems probably reflects near-surface light availability, which would have enabled photosynthesis of algal symbionts. Interestingly, live specimens of $H$. elegans, $N$. penardiana and $N$. minor were also encountered in the more humified sections of the lawn profiles between ca. $10-18 \mathrm{~cm}$, suggesting that light was able to penetrate deeper into the acrotelmic peats in the lawn environments, possibly along vertical channels created by stems or root action. Taphonomic displacement of the extant specimens down profile (for example, as a result of percolating rainwater or short-lived water table fluctuations) is also a possibility, but is less likely given the relatively even distribution of the living specimens of the three noted taxa within the 10-18 cm depth range (Fig. 4A and 4C). 
A number of Euglypha taxa recorded in the lawn samples (notably Euglypha strigosa and Euglypha tuberculata) were recorded as having a narrow/closed aperture and were classified as encysted based upon the descriptions by Heal (1962). These encysted specimens occurred exclusively in the upper living (green stem) sections of the profiles at depths of up to $5 \mathrm{~cm}$ below the surface (Fig. $4)$.

\section{Hollow microforms}

The testate amoeba assemblages from the hollow profiles were characterized by a range of hygrophilous taxa such as $H$. elegans and $H$. papilio, and some xerophilous taxa, for example, A. muscorum and H. subflava (Figs. 5, 8). Spined forms of Euglypha (e.g. E. strigosa) were also abundant in the upper $10 \mathrm{~cm}$, which are typical of wet habitats (Payne 2007; Mitchell et al. 2008). The rotifer Habrotrocha angusticollis achieved maximum abundance in the upper 1-3 $\mathrm{cm}$ in the capitulum of S. magellanicum and S. angustifolium. The dominant taxon in these environments was H. elegans, which also attained peak abundance in the uppermost $3 \mathrm{~cm}$ (Fig. 5). This suggests that its vertical distribution is influenced by light (cf. Mieczan 2009), but its presence also corresponds to a decrease in bulk density through the profile and an increase in moisture content (Fig. 5). Overall, there were more taxa in hollow environments (between 25-29) than in the hummocks and lawns, an observation also noted in Sphagnum dominated peatlands by Mieczan (2010).

An interesting minor constituent of the hollow microsites is Nebela tincta. In profile C from Mirabel Bog, for example, $4 \%$ live specimens of $N$. tincta were recorded at $2.5 \mathrm{~cm}$ (Fig 5C). This species has been described as a dry indicator taxon in a regional study of 31 eastern North American peatlands (Booth 2008), although it has also been reported in 'very wet' conditions in peatlands in southwestern Ontario (Warner 1987). The presence of $N$. tincta, albeit in low abundances in the hollow microsites, may also relate to other controls such as food availability, as the species is known to ingest a wide range of organic remains, diatoms and other testate amoebae (e.g. Euglypha and Assulina spp.) (Booth 2002; Gilbert et al. 2003). Decompositional processes may also have been more active in 
the hollow habitats relative to the other microforms, producing greater availability of other food sources, e.g., fungi and bacteria.

A further characteristic of the $N$. tincta record that is worthy of note is the slightly different distribution shown between this taxon and Nebela minor, which has been suggested to be synonymous with $N$. tincta (sensu stricto) based on recent phylogenetic work (Kosakyan et al. 2013). Nebela minor increases in the lower, more humified parts of the profiles, whilst $N$. tincta shows a more variable distribution (Fig. 5). When live specimens of the two taxa are present, they do not occur in the same samples (see for example, Fig. 5B and $\mathrm{C}$ and Fig. 4A and C). These findings are interesting, suggesting that the two morphologically distinct forms may be ecophenotypes. Further work is required to assess this in other peatlands.

Overall, the vertical distribution of live testate amoebae $(>2 \%)$ in hollow microforms spanned a maximum of $12 \mathrm{~cm}$, and comprised up to $90 \%$ of the total assemblage (Fig. 4). These values were the highest recorded in the study (Fig. 7). The majority of the live taxa consisted of $H$. elegans, particularly within the upper $4 \mathrm{~cm}$ (Fig 5). The high percentage of live specimens in the hollow profile from Mirabel Bog (Fig. 5C), might be attributed to the presence of a tamarack tree in proximity to this sampling station, which provided shade. As well as reducing light penetration, this may have resulted in changes in temperature or moisture availability that provided favourable conditions for live testate amoeba, particularly $H$. elegans. Previous studies have also found that small environmental changes such as shading and light intensity can affect the growth of the Sphagnum capitulum (Buttler et al. 1996; Mitchell et al. 2000) and Sphagnum stem length (Hayward and Clymo 1983), which may further impact testate amoeba communities. Notwithstanding this, the inferred shaded conditions at this Mirabel Bog sampling station nevertheless permitted the growth of non-compact forms of $S$. angustifolium. Other live taxa ( $>2 \%)$ present in the hollow microforms included Placocista spinosa, A. muscorum, Euglypha compressa type, E. strigosa type, H. subflava, Nebela militaris, N. minor, N. tincta and Difflugia leidyi (Figs. 5, 8). One species that was notably absent from the live assemblage was H. papillo, a common hygrophilous taxon. This may reflect the fact that the hollow sites selected were not particularly moist at the time of sampling (water tables ranged from 14-22 $\mathrm{cm}$ below the 
surface), or, as discussed above, it may reflect other factors, such as the availability of food sources. Interestingly, Jassey et al. (2012) observed that $H$. papillo has a different feeding strategy to $N$. tincta (which was present in the live assemblage) based on a study of digestive vacuole content. The former species was found to preferentially ingest ciliates, the latter fungi.

As variability in surface moisture explains the majority of testate amoeba community variance in peatlands, increased moisture typically results in higher species abundance, diversity and decreased encystment (Laminger 1978; Payne 2011). However, in this study, samples from a S. capillifoliumdominated hollow microform (Fig. 5B) yielded 63 encysted forms, which included A. muscorum and A. catinus. Encysted forms of A. muscorum were identified because of a narrowing aperture with a rounded mass of darker protoplasm. The majority of the encysted species of this taxon (44 specimens) occurred in the more humified parts of the profiles between 8-14 cm. As A. muscorum is characteristic of dry conditions, its encystment stage could reflect unfavourable, moist conditions given the proximity of the water table $(22 \mathrm{~cm})$. In the case of $A$. catinus, encystment was based on an infilled and dome-like aperture. It only occurred in a few specimens from the upper portions of the Sphagnum stem, where conditions may have become too dry. A study by Heal (1964) also found that encystment occurred in response to unfavourable environmental conditions, for example, freezing periods which exceeded the biophysical tolerances of certain taxa (Foissner 1987). Whilst encysted forms of other taxa were not found in this study, Heal (1962) noted the encystment of many forms of $H$. papilio concentrated at the Sphagnum capitulum in wet habitats. Sullivan and Booth (2011) comment on the importance of understanding the life history characteristics of individual taxa, for example, rate of reproduction and rate of encystment/uncystment. Those species that encyst have a competitive advantage over those that do not in environments with highly variable moisture availability such as peatlands in a continental setting (Booth and Zygmunt 2005). During periods of favourable conditions, specimens that can encyst may have the potential to exploit food and suitable materials for test construction (Sullivan and Booth 2011).

\section{Conclusions}


This study has provided new insights into the vertical distribution of live and encysted testate amoebae in surficial Sphagnum-dominated peats, particularly in the green moss fraction and the partly decomposed 'transitional' layer which occurs between the living stems and the more humified peat below. These micro-environments have hitherto received relatively little attention. The assemblages as a whole (live and dead) were similar to those reported previously in Sphagnum-dominated peatlands, with the greatest abundances of xerophyllous taxa occuring in hummock microforms (e.g. A. muscorum), and with increased proportions of hygrophilous taxa such as $H$. elegans and $H$. papilio in hollow microsites. The peat profiles were collected in late Spring during a prolonged period (ca. 2 weeks) of dry conditions. The community structure of the extant (live) species is thus likely to reflect seasonal (or sub-seasonal) variations in moisture availability and other physical controls that prevailed in the weeks to months prior to sampling.

The high-resolution, microform-specific data presented shows that the testate amoeba assemblages of the sampled peatlands display considerable vertical variability. This was apparent for all three microform environments investigated (hummock, hollow and lawn), with the most pronounced changes typically occurring at around $4-5 \mathrm{~cm}$ in the profiles (Figs. 3-5). In the hummock samples, for example, live specimens of A. muscorum dominated the upper $4 \mathrm{~cm}$, whilst live $H$. elegans peaked in the transitional layer $(5-9 \mathrm{~cm})$. In the lawn microforms, live specimens of $H$. petricola, $H$. papilio and $H$. sphagni attained maximum abundances in the uppermost $5 \mathrm{~cm}$ and then declined below this depth. Other taxa such as Placocista spinosa, Euglypha rotunda type, and several Difflugid taxa also peaked in lower sections of the green Sphagnum fraction and the underlying deeper, more humified sections of the hollow profiles. Marked vertical changes in assemblage composition have been noted previously in the upper sections of Sphagnum-dominated peat profiles (Gilbert and Mitchell 2006; Mazei and Bubnova 2007; Payne and Pates 2009) and have been explained by changes in light, temperature, moisture and oxygen availability, the availability of minerals for test construction, and the differential availability of food sources. Further work is required to better understand how these complex micro-habitats change with depth. The influence of multiple abiotic controls, as well as the availability of food sources, should be assessed over a full range of seasons. 
The use of data loggers to obtain continuous measurements throughout the year has considerable benefits in this regard as demonstrated previously (Sullivan and Booth 2011).

The results of the study also have implications for sampling testate amoeba assemblages for the development of calibration (training) sets in areas with deep acrotelmic peats. In particular, the vertical fluctuations noted within the green stem layer, and the lack of strong clustering of samples from specific depths for the three microforms in the DCA (Fig. 6) reinforce the need to sample across a vertical range that includes the full living stem layer to ensure that assemblage variability is captured. Some previous studies have removed the upper $1-2 \mathrm{~cm}$ of the green layer, spanning the capitulum, prior to testate amoeba analysis as this uppermost stem section has been found to display stronger assemblage variation in response to light, temperature, oxygen, moisture and mineral material for test construction (Heal 1962; Meisterfeld 1977; Booth 2002; Booth et al. 2010; Mieczan 2010). We found no clear justification for removing this layer; in some cases the uppermost $(0-2 \mathrm{~cm})$ samples yielded assemblages that were different to those at 3-4 cm, in other cases the assemblages were similar to those immediately below (Figs. 3-6). It would seem more logical to include the capitulum as part of an integrated analysis of the green stem fraction.

The study also highlights the need to better understand the relationship between the assemblages of the green layer and those of the uppermost brown layer, which has been often used in addition to (e.g. Swindles et al. 2015), or in place of (e.g. Booth 2002), the green fraction in calibration (training) sets, as it may provide a more representative, time-averaged signal for hydrological reconstructions than the green layer alone. Our results show that significant assemblage changes can occur between these two layers. The rapid decline and disappearance of $H$. sphagni, H. petricola and $H$. papilio between the uppermost stem sections of $S$. capillifolium and the underlying more humified peat in the profiles shown in Fig. 4A and 4B provides a case in point. Further work is required to more accurately delimit the two layers, to understand the decompositional and taphonomic processes that influence the associated testate amoeba assemblages, and to statistically compare the assemblages to assess how they relate to key environmental variables such as moisture availability. 
The occurrence of live testate amoebae up to a depth of $19 \mathrm{~cm}$ within the profiles also has implications for peatland-based palaeohydrological studies. This wide vertical range may reflect the presence of vertical channels within the peat, which permitted light and/or oxygen to penetrate. The introduction of significant numbers of live specimens into the deeper, well humified sections of the peat could obscure reconstructions that are based on the total assemblage from these horizons. This underlines the need to stain testate amoeba samples from surficial peat cores to provide a refined understanding of assemblage derivation. Analysis of the controls on encystment would also provide additional insights into testate amoeba ecology in near surface peat deposits. In this study, encysted species were found most commonly in the lawn and hollow profiles. Most notably, encysted forms of the xerophyllous taxon A. muscorum were more commonly found in hollow samples with higher moisture content than in adjacent samples (Fig. 5B). This preliminary finding confirms earlier observations that encystment is a response to stressed conditions (Heal 1962; 1964; Foissner, 1987). Additional sampling could be undertaken during specific seasons to assess how taphonomic processes influence live and encysted testate amoebae inhabiting acrotelmic Sphagnum stems and how communities are subsequently integrated into the palaeoecological record.

\section{Acknowledgements}

This research was funded by a Dept. Employment and Learning (DEL) Northern Ireland studentship, a UK Foundation for Canadian Studies travel grant, and a QRA New Research Workers' Award to SME and a NSERC Discovery Grant to RTP. We are grateful to Hafida El Bilali, Andreas Prokoph, Andrew Macumber, Lisa Neville, Lindsey Upiter and Ted Lamoureux for fieldwork assistance and Gill Plunkett for help with plant identifications. We thank Edward Mitchell and three anonymous reviewers for their constructive comments on earlier drafts of the manuscript.

\section{References}


Appleby, P.G., 2001. Chronostratigraphic techniques in recent sediments. In: Last, W.M., Smol, J.P. (Eds.), Tracking Environmental Changes Using Lake Sediments. Kluwer Academic Publishers, Dordrecht, pp. 171-203.

Bastien, D-F., Garneau, M. 1997. Macroscopic identification key of 36 Sphagnum species in eastern Canada. Geological Survey of Canada Miscellaneous Report 61. Natural Resources Canada. 41 pp.

Belyea, L.R., Clymo, R.S. 2001. Feedback control of the rate of peat formation. Proc. R. Soc. London: Biol. Sci. 268, 1315-1321.

Bernhard, J.M. 2000. Distinguishing live from dead foraminifera: methods review and proper applications. Micropaleontol. 46, 38-46.

Beyens, L. Ledeganck, P. Graae, B.J., Nijs, I. 2009. Are soil biota buffered against climatic extremes? An experimental test on testate amoebae in arctic tundra (Qeqertarsuaq, West Greenland). Pol. Biol. 32, 453-462.

Bobrov, A.A., Charman, D.J., Warner, B.G. 1999. Ecology of testate amoebae (Protozoa: Rhizopoda) on peatlands in western Russia with special attention to niche separation in closely related taxa. Protist 150, 125-136.

Booth, R.K. 2002. Testate amoebae as paleoindicators of surface moisture changes on Michigan peatlands: modern ecology and hydrological calibration. J. Paleolim. 28, 329-348.

Booth, R.K. 2008. Testate amoebae as proxies for mean annual water-table depth in Sphagnumdominated peatlands of North America. J. Quat. Sci. 23, 43-57.

Booth, R.K., Meyers, B. 2010. Environmental controls on pore number in Hyalosphenia papilio: implications for paleoenvironmental reconstruction. Acta Protozool. 49, 29-35.

Booth, R.K., Zymunt, J.R. 2005. Biogeography and comparative ecology of testate amoebae inhabiting Sphagnum-dominated peatlands in the Great Lakes and Rocky Mountain regions of North America. Divers. Distrib. 11 (6), 577-590.

Booth, R.K., Lamentowicz, M., Charman, D.J. 2010. Preparation and analysis of testate amoebae in peatland palaeoenvironmental studies. Mires and Peat 7, 1-7.

Buttler, A., Warner, B.G., Grosvernier, P., Matthey, Y. 1996. Vertical patterns of testate amoebae (Protozoa: Rhizopoda) and peat-forming vegetation on cutover bogs in the Jura, Switzerland. New Phytol. 134 (2), 371-382.

Chambers, F.M., Booth, R.K., De Vleeschouwer, F., Lamentowicz, M., Le Roux, G., Mauquoy, D., Nichols, J.E. \& van Geel, B. 2011. Development and refinement of proxy-climate indicators from peats. Quat. Int. 268, 21-33.

Charman, D.J. 2007. Summer water deficit variability controls on peatland water-table changes: implications for Holocene palaeoclimate reconstructions. The Holocene 17, 217-227. 
Charman, D.J., Hendon, D., Packman, S. 1999. Multiproxy surface wetness records from replicate cores on an ombrotrophic mire: implications for Holocene palaeoclimate records. J. Quat. Sci. 14, 451-463.

Charman, D.J., Hendon, D., Woodland, W.A. 2000. The Identification of Testate Amoebae (Protozoa: Rhizopoda) in Peats, Quaternary Research Association Tech. Guide 9. QRA London.

Charman, D.J., Brown, A.D., Hendon, D., Karofeld, E. 2004. Testing the relationship between Holocene peatland palaeoclimate reconstructions and instrumental data at two European sites. Quaternary Science Reviews 23, 137-143.

Charman, D. J., Blundell, A. \& ACCROTELM members. 2007. A new European testate amoebae transfer function for palaeohydrological reconstruction on ombrotrophic peatlands. J. Quat. Sci. 22, 209-221.

Charman, D.J., Barber, K.E., Blaauw, M., Langdon, P.G., Mauquoy, D., Daley, T.J., Hughes, P.D.M., Karofeld, E. 2009. Climate drivers for peatland palaeoclimate records. Quaternary Science Reviews 28, 1811-1819.

Climate-Data.org, 2016. Climate: Mirabel. en.climate-data.org/location/28081/ Accessed 2 Feb 2016. Clymo, R.S. 1984. The limits to peat bog growth. Phil. Trans. Roy. Soc. London B 303, 605-654.

Corbet, S.A. 1973. An illustrated introduction to the testate rhizopods in Sphagnum, with special reference to the area around Malham Tarn, Yorkshire. Field Studies 3, 801-838.

Crum, H.A., Anderson, L.E. 1981. Mosses of Eastern North America. 2 vols. Columbia University Press, New York. 1330 pp.

Daniels, R. E; Eddy, A. 1990. Handbook of European Sphagna. London, HMSO, 263 pp.

Elliott, S.M., Roe, H.M., Patterson, R.T. 2011. Testate amoebae as indicators of hydroseral change: An 8500 year record from Mer Bleue Bog, eastern Ontario, Canada. Quat. Int. 268, 128-144.

Environment Canada, 2016. Canadian Climate Normals 1981-2010. Environment Canada. http://climate.weather.gc.ca/climate_normals/results_1981_2010_e.html?stnID=4337\&lang=e\&d Code $=1 \&$ province $=$ ONT\&provBut $=$ Go\&month $1=0 \&$ month $2=12$ Retrieved 2 Feb 2016.

Foissner, W. 1987. Soil protozoa: fundamental problems, ecological significance, adaptation in ciliates and testaceans, bioindicators and a guide to the literature. Prog. Protistol. 2, 69-212.

Gilbert, D., Mitchell, E.A.D., Amblard, C., Bourdier, G., Francez, A.J. 2003. Population dynamics and food preferences of the Testate amoeba Nebela tincta major-bohemica-collaris Complex (Protozoa) in Sphagnum peatland. Acta Protozool. 42, 99-104.

Gilbert, D., Mitchell, E.A.D. 2006. Microbial diversity in Sphagnum peatlands. In: Martini I.P., Martinez Cortizas, A., Chesworth, A. (eds). Peatlands: Evolution and records of environmental and climate changes. Elsevier B. V chapter 13 287-317 pp.

Hayward, P. M., Clymo, R.S. 1983. The growth of Sphagnum: experiments on, and simulation of, some effects of light flux and water-table depth. J. Ecol. 71, 845-63. 
Heal, O.W. 1962. The abundance and microdistribution of testate amoebae (Protozoa: Rhizopoda) in Sphagnum. Oikos 13, 35-47.

Heal, O.W. 1964. Observations on the seasonal and spatial distribution of Testacea (Protozoa: Rhizopoda) in Sphagnum. J. Animal Ecol. 33, 395-412.

Hendon, D., Charman, D.J. 1997. The preparation of testate amoebae (Protozoa: Rhizopoda) samples from peat. Holocene 7, 199-205.

Hendon, D., Charman, D.J. 2004. High resolution peatland water table changes for the past 200 years: the influence of climate and implications for management. Holocene 14, 125-134.

Hendon, D., Charman, D.J., Kent, M. 2001. Palaeohydrological records derived from testate amoebae analysis from peatlands in northern England: within-site variability, between-site comparability and palaeoclimatic implications. Holocene 11, 127-48.

Jassey, V.E.J., Chiapusio, G., Mitchell, E.A.D., Binet, P., Toussaint, M., Gilbert, D. 2011. Fine-scale horizontal and vertical micro-distribution patterns of testate amoebae along a narrow fen-bog gradient. Environ. Microbiol. 61(2), 374-385.

Jassey, V.E.J., Shimano, S., Dupuy, C., Toussaint, M.L., Gilbert, D. 2012. Characterizing the feeding habits of the testate amoebae Hyalosphenia papilio and Nebela tincta along a narrow "Fen-Bog" gradient using digestive vacuole content and ${ }^{13} \mathrm{C}$ and ${ }^{15} \mathrm{~N}$ isotopic analyses. Protist 163, 451-464.

Joyal, R. 1970. Description de la tourbière à Sphaignes Mer Bleue près d'Ottawa. 1. Végétation. Can. J. Bot. 48, 1405-1418.

Kosakyan, A., Gomaa, F. Mitchell, E.A.D., Heger, T.J., Lara, E. 2013. Using DNA-barcoding for sorting out protist species complexes: A case study of the Nebela tincta-collaris-bohemica group (Amoebozoa; Arcellinida, Hyalospheniidae). Eur. J. Protistol. 49, 222-237.

Lafleur, P.M., Hember, R.A., Admiral, S.W., Roulet, N.T. 2005. Annual and seasonal variability in evapotranspiration and water table at a shrub-covered bog in southern Ontario, Canada. Hydrol. Processes 19, $3533-3550$.

Lamare, A., Magnan, G., Garneau, M., Boucher, E. 2013. A testate amoeba-based transfer function for paleohydrological reconstruction from boreal and subarctic peatlands in northeastern Canada. Quart. Int. 306, 88-96.

Lamentowicz, M., Mitchell, E.A.D. 2005. The ecology of testate amoebae (Protists) in Sphagnum in North-western Poland in relation to peatland ecology. Microb. Ecol. 50, 48-63.

Lamentowicz, Ł., Lamentowicz, M., Gąbka, M. 2008. Testate amoebae ecology and a local transfer function from a peatland in western Poland. Wetlands 28, 164-175.

Lamentowicz, M., Gałka, M., Lamentowicz, Ł, Obremska, M., Kühl, N., Lücke, A, Jassey, V.E.J. 2015. Reconstructing climate change and ombrotrophic bog development during the last 4000 years in northern Poland using biotic proxies, stable isotopes and trait-based approach Palaeogeog., Palaeoclim. Palaeoecol. 418, 261-267. 
Laminger, H. 1978. The effects of soil moisture fluctuations on the testacean species Trinema enchelys (Ehrenberg) Leidy in a high mountain brown-earths-podsol and its feeding behaviour. Archiv Protist. 120, 46-454.

Laminger, H.S.R. Sturn, R. 1984. Einfluß der Ernährung auf die Enzystierung und Exzystierung von Testacea (Protozoa, Rhizopoda). Pedobiologia 27, 241-244.

Loeblich, A.R., Tappan, H. 1961. Remarks on the systematics of the Sarkodina (Protozoa), renamed homonyms and new and validated genera. Proc. Biol. Soc. Wash. 74, 213-234

Loisel, J., Garneau, M. 2010. Late Holocene palaeoecohydrology and carbon accumulation estimates from two boreal peat bogs in eastern Canada: Potential and limits of multi-proxy archives. Palaeogeog., Palaeoclim. Palaeoecol. 291, 492-533.

Lousier, J.D. 1974. Response of soil testacea to soil moisture fluctuations. Soil Moisture Biochem. $6(4), 235-239$.

Ma, J.Z, Bu, Z.J., Zheng, X.X., Ge, J.L., Wang, S.Z. 2015. Effects of shading on relative competitive advantage of three species of Sphagnum. Mires and Peat, 16, Article 04, 1-17, http://www.mires-and-peat.net/, ISSN 1819-754X

MacPherson, J.B. 1967. Raised shorelines and drainage evolution in the Montreal lowlands. Cahiers de géographie du Québec 11, 343-360.

Malmer, N, Svensson, B, M, Wallén, B. 1994. Interactions between Sphagnum mosses and field layer vascular plants in the development of peat-forming systems. Folia Geobotanica et Phytotaxonomica 29, 483-496.

Mazei, Y.A., Bubnova, O.A. 2007. Species composition and structure of testate amoebae community in a Sphagnum bog at the initial stage of its formation. Biol. Bull. 34, 619-628.

Mazei, Y.M., Tsyganov, A.N. 2007. Species composition, spatial distribution and seasonal dynamics of testate amoebae community in a Sphagnum bog (Middle Volga region, Russia). Protistol. 5, 156-206.

McCarter, C.P.R., Price, J.S. 2012. Ecohydrology of Sphagnum moss hummocks: mechanisms of capitula water supply and simulated effects of evaporation. Ecohydrol. 7, 33-44.

McQueen, C.G. 1989. A biosystematic study of Sphagnum capillifolium Sensu Lato. The Bryologist 92(10), 1-24.

Meisterfeld, R. 1977. Die horizontale und vertikale Verteilung der Testaceen (Rhizopoda: Testacea) in Sphagnum. Archiv Hydrobiol. 79, 319-356.

Meisterfeld, R. 1978. Die Struktur von Testaceenzönosen (Rhizopda, Testacea) in Sphagnum unter besonderer Berücksichtigung ihrer Diverität. Ver. Gesell. Ökologie 7, 441-450.

Mieczan, T. 2009. Ecology of testate amoebae (Protists) in Sphagnum peatlands of eastern Poland: Vertical micro-distribution and species assemblages in relation to environmental parameters. Ann. Limnol. - Int. J. Lim 45, 41-49. 
Mieczan, T. 2010. Vertical micro-zonation of testate amoebae and ciliates in peatland waters in relation to potential food resources and grazing pressure. Int. Rev. Hydrobiol. 95, 86-102.

Mitchell, E.A.D., Gilbert, D. (2004) Vertical micro-distribution and response to nitrogen deposition of testate amoebae in Sphagnum. J. Euk. Microbiol. 51(4), 480-490.

Mitchell, E.A.D., Buttler A., Grosvernier P., Rydin H., Albinsson C., Greenup A.L., Heijmans, M.M.P.D., Hoosbeck, M.R., Saarinen, T. 2000. Relationships among testate amoebae (Protozoa), vegetation and water chemistry in five Sphagnum- dominated peatlands in Europe. New Phytol. $146,95-106$.

Mitchell, E.A.D., Payne, R.J., Lamentowicz, M. 2008. Potential implications of differential preservation of testate amoeba shells for paleoenvironmental reconstruction in peatlands. $\mathrm{J}$. Paleolim. 40(2), 603-618.

Morris, P.J., Waddington, J.M., Benscoter, B.W., Turetsky, M.R. 2011. Conceptual frameworks in peatland ecohydrology: Looking beyond the two-layered (acrotelm-catotelm) model. Ecohydrology 4, 1-11.

Mott, R.J., Camfield, M., 1969. Palynological studies in the Ottawa area. Geological Survey of Canada Paper, 38-69.

Muller, S.D., Richard, P.J.H., Larouchel, A.C. 2003. Holocene development of a peatland (southern Québec): a spatio-temporal reconstruction based on pachymetry, sedimentology, microfossils and macrofossils. The Holocene 13, 649-664

Nicholls, K.H. 2006. Cryptodifflugia leachi n. sp., a minute new testate rhizopod species (Rhizopoda: Phryganella). Acta Protozool. 45, 295-299.

Niinemets, E., Pensa, M., Charman, D.J. 2011. Analysis of testate amoebae in Selisoo Bog, Estonia: local variability and implications for palaeoecological reconstructions in peatlands. Boreas 40, 367-378.

Ogden, C.G., Hedley, R.H. 1980. An atlas of freshwater testate amoebae. British Museum (Natural History), London. 222 pp.

Payne, R.J. 2007. Laboratory experiments on testate amoebae preservation in peats: implications for palaeoecology and future studies. Protozool. 46, 325-332.

Payne, R.J. 2011. Can testate amoeba-based palaeohydrology be extended to fens? J. Quat. Sci. 26, $15-27$.

Payne, R., Pates, J.M. 2009. Vertical stratification of testate amoebae in the Elatia Mires, northern Greece: palaeoecological evidence for a wetland response to recent climate change, or autogenic processes? Wetlands Ecol. Man. 17, 355-364.

Payne, R.J., Telford, R.J., Blackford, J.J., Blundell, A., Booth, R.K., Charman, D.J., Lamentowicz, L., Lamentowicz, M., Mitchell, E.A.D., Potts, G., Swindles, G.T., Warner, B.G., Woodland, W. 2011. 
Testing peatland testate amoebae transfer functions: Appropriate methods for clustered training sets. Holocene 22, 819-825.

Penard, E. 1902. Les Rhizopodes du bassin du Léman Kündig, Genève.

Prokoph, A., Patterson, R.T. 2004. Application of wavelet and discontinuity analysis to trace temperature changes: Eastern Ontario as a case study. Atmosphere Ocean 42, 201-212.

Quinty, F., Rochefort, L. 2003. Peatland restoration guide, 2nd edition. Canadian Sphagnum peat moss Association and New Brunswick Department of Natural Resources and Energy, Québec. 106 pp.

Robroek, B.J.M., Limpens, J., Breeuwer, A., van Ruijven, J., Schouten, M.G.C. 2007. Precipitation determines the persistence of hollow Sphagnum species on hummocks. Wetlands 27, 979-986.

Rydin, H., Jeglum, H. 2006. The Biology of Peatlands. Oxford University Press, Oxford. 354 pp.

Rydin, H., Gunnarsson, U., Sunderberg, S. 2006. The role of Sphagnum in peatland development and persistence. In: Boreal Peatland Ecosystems, Wider, R.W. Witt, D.H. (eds) 47-94 p. SpringerVerlag, Berlin Heidelberg.

Schönborn, W. 1962. Zur Ökologie der sphagnikolen, bryokolen und terrikolen Testaceen. Limnologica 1, 231-254.

Schönborn, W. 1963. Die stratigraphie lebender Testaceen im Sphagnetum der Hochmoore. Limnologica 1, 315-321.

Scott, D.B., Medioli, F.S. 1980. Living vs. Total Foraminiferal Populations: Their Relative Usefulness in Paleoecology. J. Paleontol. 4, 814-831.

Sullivan, M. E., Booth, R.K. 2011. The potential influence of short-term environmental variability on the composition of testate amoeba communities in Sphagnum peatlands. Microb. Ecol. 62, 80-93.

Swindles, G.T., Roe, H.M. 2007. Examining the dissolution characteristics of testate amoebae (Protozoa: Rhizopoda) in low $\mathrm{pH}$ conditions: Implications for peatland palaeoclimate studies. Palaeogeog., Palaeoclim. Palaeoecol. 252, 486-496.

Swindles, G.T., Roe, H.M., Charman, D.J., Sansum, P.A. 2009. Environmental controls on peatland testate amoebae (Protozoa: Rhizopoda) in the North of Ireland: implications for paleoclimate studies. J. Paleolim. 42, 123-140.

Swindles, G.T., Holden, J, Raby, C.L., Turner, T.E., Blundell, A., Charman, D.J., Menberu, M.W., Kløve, B. 2015. Testing peatlands water-table depth transfer functions using high resolution hydrological monitoring data. Quat. Sci. Rev. 120, 107-117.

Tolonen, K., Warner, B.G., Vasander, H. 1992. Ecology of testaceans (Protozoa: Rhizopoda) in mires in southern Finland: 1. Autoecology. Archiv fuer Protistenkunde 142, 119-138.

Vincke, S., Ledeganck, P., Beyens, L., Van de Vijver, B. 2004. Soil testate amoebae from subAntarctic Îles Crozet. Antarctic Sci. 16(2), 165-174.

Warner, B.G. 1987. Abundance and diversity of testate amoebae (Rhizopoda, Testacea) in Sphagnum peatlands in southwestern Ontario, Canada. Archiv. für Protist. 133, 173-189. 
Warner, B.G., Asada, T., Quinn, N.P. 2007. Seasonal influences on the ecology of testate amoebae (protozoa) in a small Sphagnum peatland in southern Ontario, Canada. Microb. Ecol. 54, 91-100.

Weather Network, 2016. Weather Network Weather Statistics Pointe Au Chene, Quebec. http://www.theweathernetwork.com/ca/api/sitewrapper/index $\mathrm{b}=\% 2 \mathrm{Fstatistics} \% 2 \mathrm{~F} \& \mathrm{p}=\% 2 \mathrm{Fforeca}$ sts $\% 2$ Fstatistics $\% 2$ Findex\&url=\%2Fstatistics $\% 2 F$ caon $0009 \% 2$ Falfred $\% 2 F \% 2 F \% 2 F \% 3 \mathrm{~F}$ Accessed 2 Feb 2016.

Woodland, W.A., Charman, D.J., Sims, P.C. 1998. Quantitative estimates of water tables and soil moisture in Holocene peatlands from testate amoebae. The Holocene 8 (3), 261-273.

Yu, Z., Campbell, I.D., Campbell, C., Vitt, D.H., Bond, G.C., Apps, M.J. 2003. Carbon sequestration in western Canadian peat highly sensitive to Holocene wet-dry climate cycles at millennial timescale. The Holocene 13(6), 801-808.

\section{Figures}

Fig. 1 Map showing the location of Mer Bleue (1), Mirabel (2) and Alfred (3) peatlands.

Fig. 2 Schematic diagram showing hummock, lawn and hollow microforms. The transition layer between the live and more decomposed plant stems is indicated with arrows.

Fig. 3 Hummock profiles: A (Sphagnum capillifolium) monolith. B (Sphagnum fuscum) monolith. C (Sphagnum fuscum) monolith. Abundance of species $>2 \%$ shown. Red bars indicate $\%$ live with only live $>2 \%$ shown. Water table depth measurements taken at the time of sampling are indicated. The upper 'green' profile sections were dominated by stems in vertical growth position; the lower 'brown' monolith sections typically showed increasing humification with depth. For a fuller description of these zones and the intermediate transitional layer see Fig. 2. Taxonomic note: some N. American testate amoeba studies have not identified Hyalosphenia ovalis because of confusion with $N$. tincta and H. papillo (see Booth and Meyers, 2010). We used the criteria detailed in Charman et al. (2000).

Fig. 4 Lawn profiles: A (Sphagnum capillifolium) monolith. B (Sphagnum capillifolium) monolith. C (Sphagnum capillifolium) monolith. Abundance of species $>2 \%$ shown. Red bars indicate \% live with only live $>2 \%$ shown and asterisks denote encysted taxa. Water table measurements taken during sampling are indicated. For a fuller description of the monolith characteristics and the transitional layer see Fig. 2.

Fig. 5 Hollow profiles: A (Sphagnum magellanicum) monolith. B (Sphagnum capillifolium) monolith. C (Sphagnum angustifolium) monolith. Abundance of species $>2 \%$ shown. Red bars indicate $\%$ live with only live $>2 \%$ shown and asterisks denote encysted taxa. For a description of the transitional 
layer see Fig. 2. Water table depth measurements taken at the time of sampling are indicated. Note: further comments on the distribution of the Sphagnum species of the hollow stations is given in Supplementary Table 1B.

Fig. 6 Detrended correspondence analysis (DCA) results showing principal patterns of variation in the testate amoeba assemblages. The analyses were run on the total counts from the unhumified (green living) monolith samples $(\mathrm{n}=65)$ that yielded $>5 \%$ live specimens for at least one taxon. Clusters are encircled for the three microform environments and core depth information is given.

Fig. 7 Live testate amoeba abundances $(>2 \%)$ in the hummock, lawn and hollow microforms from the three peatland sites.

Fig. 8 Simplified synthesis figure showing the living testate amoeba distribution in the sampled hummock, lawn and hollow profiles. The position of the profiles with respect to the water table at the time of sampling and the associated vegetation characteristics are indicated. For the lawn and hollow environments, the testate amoeba assemblage data from profiles that overlapped in height are combined. See Figs. 3-5 for full details of the assemblage composition at the individual sampling stations (A-C). 